\title{
The Innovative Development of Industrial Production in the Digital Economy of Russia
}

\author{
Oksana E. Ivanova 1[ORCID 0000-0003-4498-8279], \\ Mikhail S. Abrashkin 2*[ORCID 0000-0003-0234-6446], \\ Martin Sikyr 3[ORCID 0000-0002-4623-1133], \\ Yury V. Daneykin 4[ORCID 0000-0001-7181-2557]
}

\author{
${ }^{1}$ Kostroma State Agricultural Academy, Kostroma region, Russia \\ ${ }^{2}$ LEONOV Moscow Region University of Technology, Korolev, Russia \\ ${ }^{3}$ University of New York in Prague, Prague, Czech Republic \\ ${ }^{4}$ Yaroslav-the-Wise Novgorod State University, Veliky Novgorod, Russia \\ abrashkinms@mail.ru
}

\begin{abstract}
The sustained competitiveness of industrial enterprises is determined by their ability to constantly innovate their methods, products and services. The article analyzes the innovative activity of individual Russian industrial enterprises and proposes strategic priorities for the innovative development of industrial production in Russia in the context of digital transformation. The activities of 384 industrial enterprises of various profiles from 2015 to 2019 were analyzed on the basis of publicly available accounting (financial) statements. The analyzed sample of enterprises is representative with a confidence level of $95 \%$ and an error of 5\% for the entire set of industrial enterprises in Russia. To specify the innovative development of industrial production in the Russian digital economy, the economic development and financial stability of selected Russian industrial enterprises, and the determinants of the innovative development within digital transformation of the economy are analyzed. The results imply the need to transform ways of managing and studying the functioning of industrial production and innovative trends. The analysis led to the definition of strategic priorities of the innovative development of industrial production in Russia based on control mechanisms ensuring stable economic growth and increasing competitiveness of Russian industrial enterprises within the digital economy. The achieved results can be used in predicting the development of the situation at different government levels to ensure a successful digital transformation of industrial production.
\end{abstract}

Keywords: industrial enterprises, innovative activities, industrial production, digital economy

\section{INTRODUCTION}

The transition of the world economy from industrial to innovative form raises the need to study new ways of managing innovative activities of organizations [1]. Particularly important are the issues of transforming the results of research and development and industrial innovative activities into the digital environment [2]. From the point of view of increasing the competitiveness of Russian industrial products on world markets, the key is the innovative development of industrial production. The process of managing innovative activities is therefore becoming an important challenge for Russian industrial producers [3].

The modernization of the Russian economy based on innovative activities prospectively increases the share of innovative products in the total volume of sales in the domestic and foreign markets [4].

To fulfill this perspective, it is important to improve the existing mechanisms for managing innovative activities of organizations and to find new ways of anticipating the development of the situation at different levels of management [5]. 
Research on innovative development in the digital economy $[2,6,7]$ identifies digitization as the cause of extensive and radical transformations in many business areas and as a source of huge opportunities as well as significant risks.

The mentioned approaches to the innovative development of industrial production in the digital economy of Russia indicate the need for a factual study of key factors of innovative development at various levels - technological, organizational, marketing, or ecological.

\section{MATERIALS AND METHODS}

The paper summarizes the results of the authors' analysis of innovative activities of 384 selected Russian industrial enterprises from 2015 to 2019 to propose strategic priorities of the innovative development of industrial production in Russiawithin the digitization of the economy.

The analysis is based on publicly available accounting (financial) statements published from 2015 to 2019 on the Interfax portal [8]. The analyzed sample of enterprises including industrial enterprises with various scopes of business is representative, with a confidence level of $95 \%$ and an error of $5 \%$ for the whole set of industrial enterprises in Russia.

The theoretical analysis is based on the findings concerning the management of innovative activities of industrial enterprisesand the digital economy of domestic and foreign researchers. These findings were supplemented by specific statistical data on the activities of selected industrial enterprises. The result of the analysis is the definition of strategic priorities of the innovative development of Russian industrial enterprises based on control mechanisms ensuring stable economic growth and increasing competitiveness.

\section{RESULTS}

\subsection{Indicators of the development of analyzed enterprises}

The analysis is based on the assumption that the management of innovative activities of Russian industrial enterprises is possible through a set of control actions that reflect the variability of the development of the situation. The analysis is performed and presented in three stages: 1) indicators of the development of analyzed enterprises, 2) indicators of solvency and financial stability of analyzed enterprises, and 3) directions of innovative activities of Russian industrial enterprises.

At the end of 2019, the industrial production in Russia was represented by 349900 industrial enterprises. The sample of 384 analyzed industrial enterprises included $16 \%$ of micro-enterprises with an average annual number of employees of less than 15 employees, $33 \%$ of small enterprises with an average annual number of employees ranging from 15 to 100 employees, $19 \%$ of medium-sized enterprises with an average annual number of employees ranging from 101 to 250 employees, $21 \%$ of large enterprises with an average annual number of employees ranging from 251 to 1000 employees, and $11 \%$ of large-scale enterprises with an average annual number of employees of more than 1,000 employees (Figure 1).

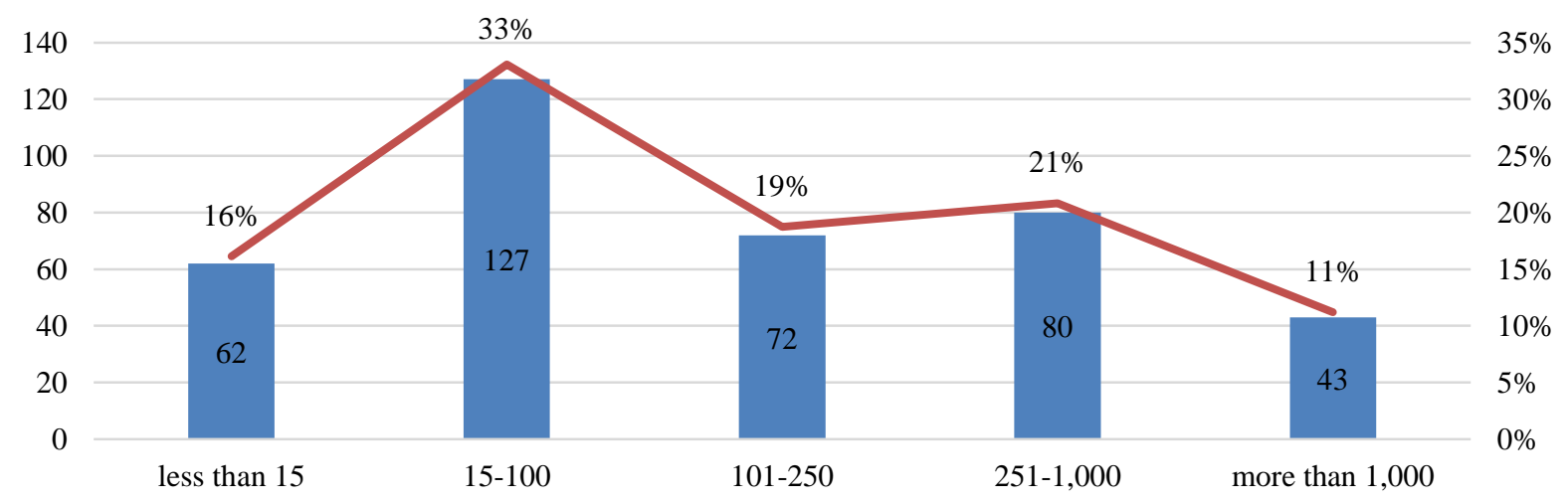

Figure 1. Distribution of analyzed enterprises by the average annual number of employees Source: Compiled by the authors

Most of the micro-enterprises were engaged in food production (14\%) and wood processing (11\%). Most of the small enterprises were engaged in food production $(13 \%)$ and metal processing $(9 \%)$. Most of the medium-sized enterprises were engaged in metal processing (18\%). Most of the large 
enterprises were engaged in electricity, gas, and steam generation, production, and distribution $(11 \%)$, as well as most of the large-scale enterprises $(14 \%)$.

In general, the intensification of industrial growth is essential for increasing labor productivity and reducing costs [9].

As a result of the intensification of industrial growth, the materialization of labor (capital-labor ratio) in the structure of resources used increases [10], as the level of labor productivity increases due to innovative activities [11].

The analysis of the distribution of analyzed enterprises by the level of capital-labor ratio showed that there were almost a third of enterprises (32\%) that had a low level of capital-labor ratio of 250000 rubles (about 2760 euros) per person. Furthermore, there were $13 \%$ of enterprises that had an average level of capital-labor ratio of 1000000 to 2000000 rubles (about 11040 to 22079 euros) per person and there were $5 \%$ of enterprises that had a high level of capital-labor ratio of over 10000000 rubles (about 110395 euros) per person (Figure 2a). The main

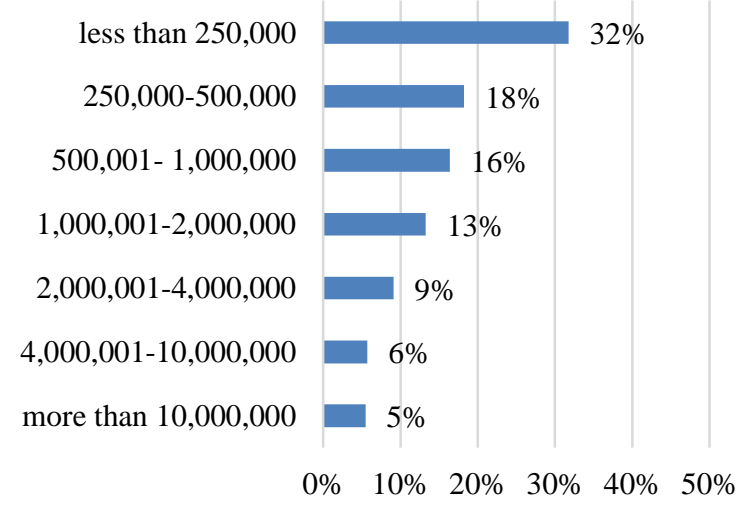

a) Distribution of analyzed enterprises by the capital-labor ratio (rubles/person) activity with a low level of capital-labor ratio was the clothing production ( $16 \%$ of enterprises), with a medium level of capital-labor ratio it was the production of non-metallic products $(12 \%$ of enterprises) and with a high level of capital-labor ratio, it was the generation, production, and distribution of electricity, gas, and steam (33\% of enterprises).

The analysis of the distribution of analyzed enterprises by labor productivity showed that less than half of the enterprises (44\%) had labor productivity levels ranging from 1000000 to 4000000 rubles (about 11040 to 44158 euros) per person. Furthermore, there were $20 \%$ of enterprises that had a low level of labor productivity of up to 1000000 rubles (about 11040 euros) per person, but there were also $4 \%$ of enterprises that had a high level of labor productivity over 20000000 rubles (about 220789 euros) per person (Figure 2b). The activities with a low level of labor productivity included clothing production and wood processing (10\% of enterprises). The activity with the highest level of labor productivity was chemical production (23\% of enterprises)

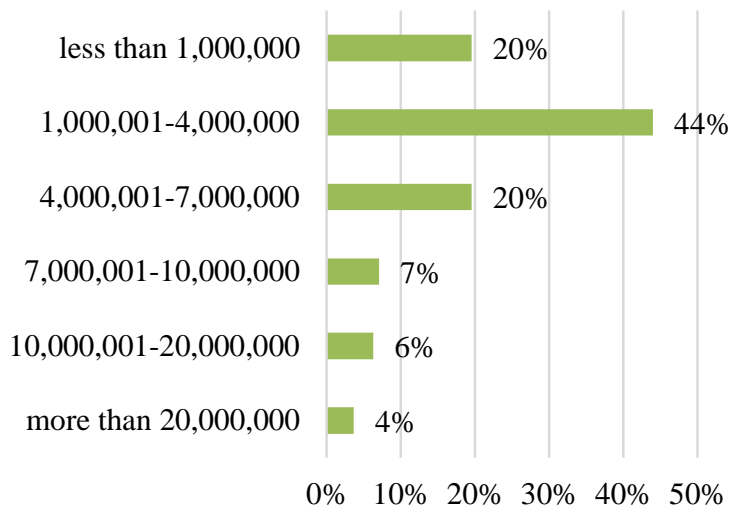

b) Distribution of analyzed enterprises by labor productivity (rubles/person)

Figure 2. Distribution of analyzed enterprises by capital-labor ratio and labor productivity Source: Compiled by the authors

\subsection{Indicators of solvency and financial stability of analyzed enterprises}

Achieving the financial stability of Russian industrial enterprises requires compliance with internal standards derived from the recommendations of the financial sector [12].

To assess solvency and financial stability of analyzed enterprises, liquidity ratios were used, which characterize the extent to which the current assets of an enterprise cover its short-term obligations, and also the profitability, which shows the rate of using the assets of an enterprise as sources of value (Figure 3).

In 2019, 55\% of analyzed enterprises had difficulty covering their short-term obligations, which was confirmed by the cash ratio (CAR) less than 0.2 , while $26 \%$ of analyzed enterprises did not experience problems with their solvency (Figure 3a). A similar trend was confirmed by the quick ratio $(\mathrm{QR})$, which was less than 0.7 in the case 
of $67 \%$ of analyzed enterprises, which indicates a potential problem in covering obligations in worse times (Figure $3 b$ ). At the end of 2019, $45 \%$ of analyzed enterprises had satisfactory solvency, which was confirmed by the current ratio (CUR) in the range of $1.0 \leq \mathrm{CUR} \leq 2.0$. In addition, $40 \%$ of analyzed enterprises had more current assets than short-term obligations (Figure 3c). The analysis of the autonomy ratio (AR) showed that $57 \%$ of analyzed enterprises were not dependent on creditors, while $43 \%$ of analyzed enterprises had low financial stability (Figure $3 d$ ). The analysis of the financial situation and long-term solvency of analyzed enterprises showed that at the end of 2019 , $65 \%$ of analyzed enterprises had a sufficient number of own resources for the development of their

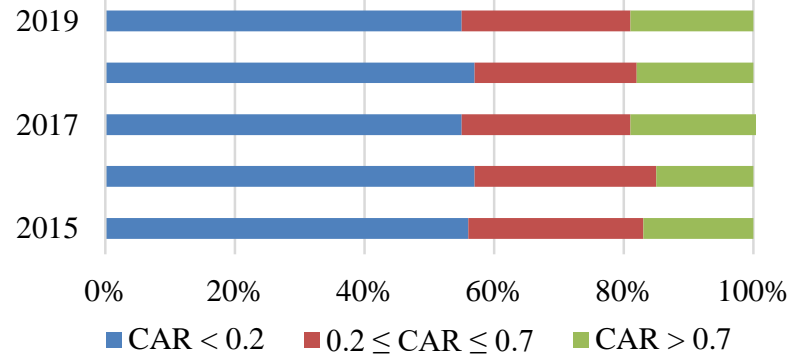

a) Distribution of analyzed enterprises by cash ratio (CAR)

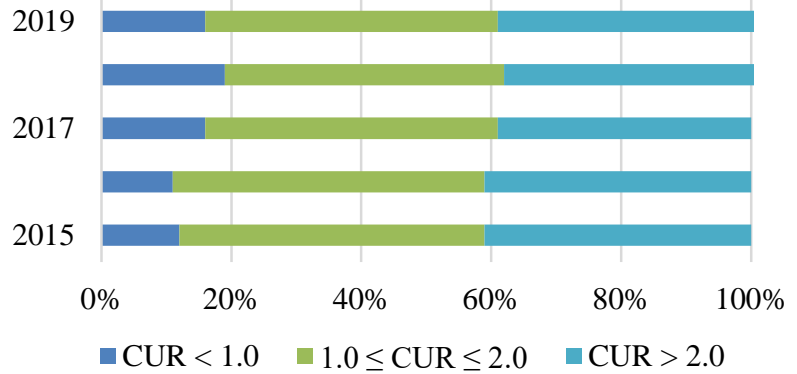

c) Distribution of analyzed enterprises by the current ratio (CUR)

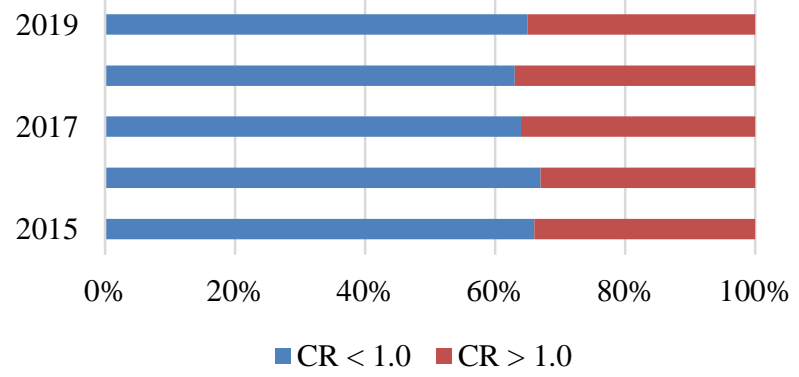

e) Distribution of analyzed enterprises by capitalization ratio (CR) business activities. On the other hand, $35 \%$ of analyzed enterprises were more dependent on external sources of funding, which was confirmed by the capitalization ratio $(\mathrm{CR})$ greater than 1.0 (Figure $3 e$ ). The analysis of the sales profitability (SP) showed that the total number of unprofitable enterprises among analyzed enterprises increased by $6 \%$ in 2019 compared to 2015 . The sales profitability in the range of $0.0 \leq \mathrm{SP} \leq 0.5$ showed that $34 \%$ of analyzed enterprises were in the zone of efficient use of all available resources (Figure 3f).

The analysis also showed that between 2015 and 2019 , more than $70 \%$ of the surveyed companies reported a profit (Figure 4).

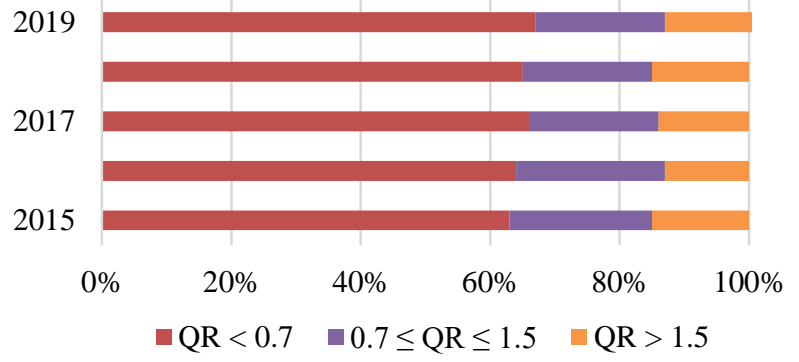

b) Distribution of analyzed enterprises by the quick ratio (QR)

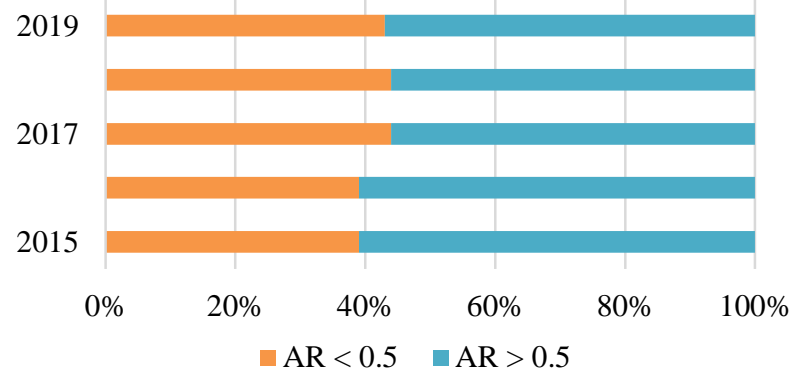

d) Distribution of analyzed enterprises by autonomy ratio (AR)

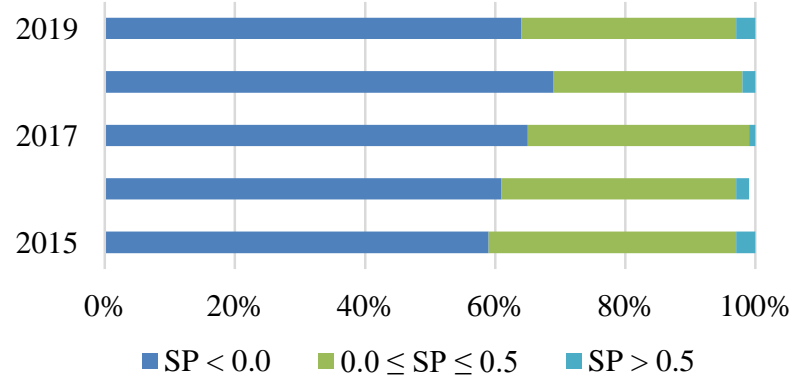

f) Distribution of analyzed enterprises by sales profitability (SP)

Figure 3. Distribution of analyzed enterprises by the solvency and financial stability

Source: Compiled by the authors 


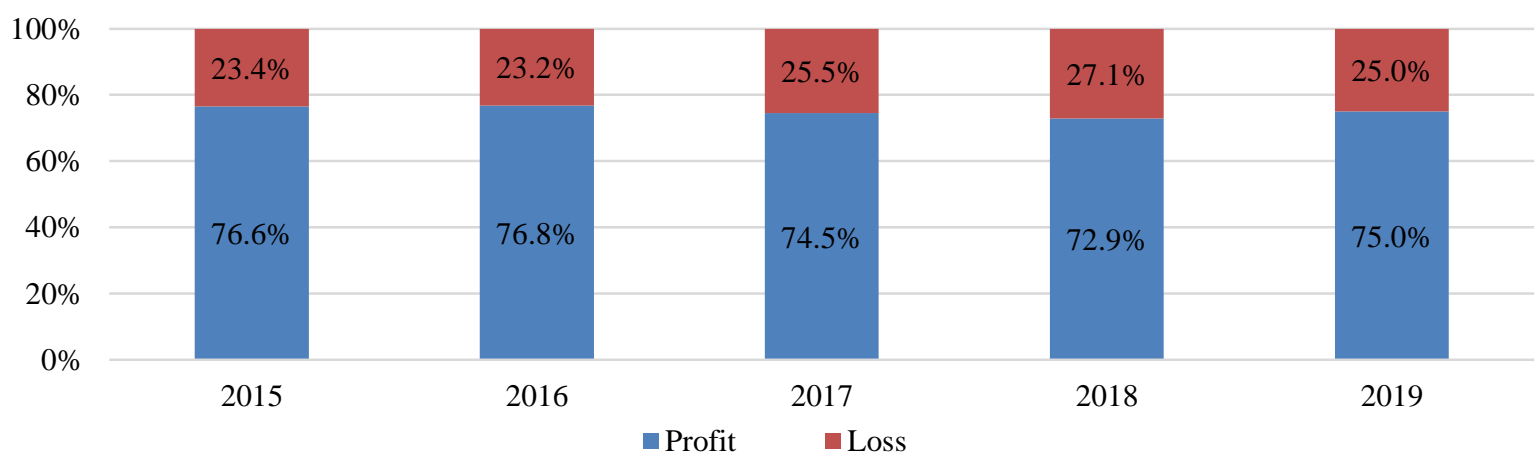

Figure 4. Distribution of analyzed enterprises by financial results Source: Compiled by the authors

The innovative development of industrial production is impossible without investment in research and development (R\&D) [13]. The analysis showed that R\&D expenses were reported by $7 \%$ of analyzed enterprises in 2019 (Figure 5). They were enterprises engaged in the production of petroleum, chemical or electronic products, and the generation, production, and distribution of electricity, gas, steam.

The authors believe that further investment in $R \& D$ is possible thanks to the availability of enterprises' resources and financial support from the public sector [14].

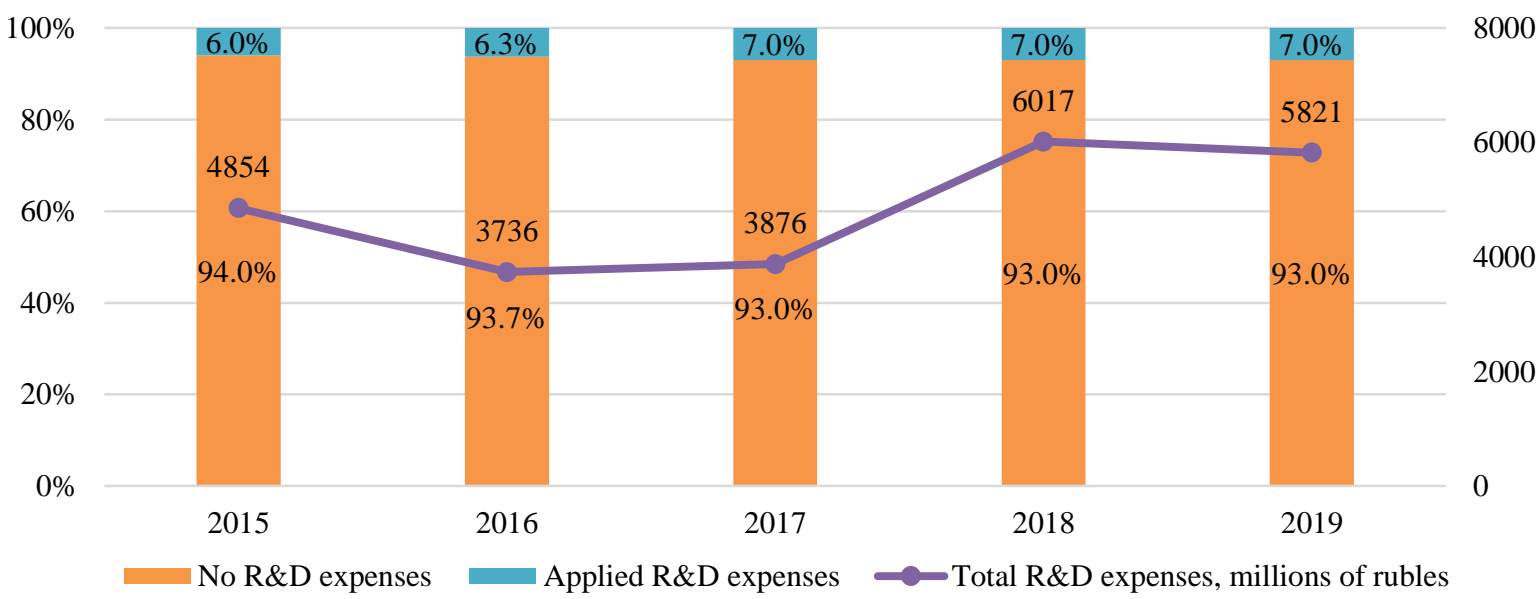

Figure 5. Distribution of analyzed enterprises by R\&D expenses

Source: Compiled by the authors

\subsection{Directions of innovative activities of Russian industrial enterpriseswithin digitization ofthe economy}

The starting point for managing the innovative activities of industrial organizations should be the identification of problems and opportunities based on a cognitive approach to the analysis of complex situations [15]. With this in mind, the authors proposed a set of control measures for the management of innovative activities of Russian industrial enterprises within the digital economy (Figure 6).

The national project "Digital Economy of the Russian Federation" [6] assumes the introduction of digital technologies in the economic and social field, the creation of conditions for high-tech businesses, the increase of the country's competitiveness in the global market, and the improvement of the national security. Project initiatives also include information infrastructure, human resources for the digital economy, information security, and digital technologies.

These control measures can serve as a basis for the construction of cognitive maps reflecting subjective ideas about the management of innovative activities in Russian industrial enterprises. In addition, the proposed approach to managing the parameters of innovative activities will enable government institutions to implement control mechanisms to stimulate innovative activities aimed at improving the main macroeconomic indicators characterizing economic growth within digital transformation. 


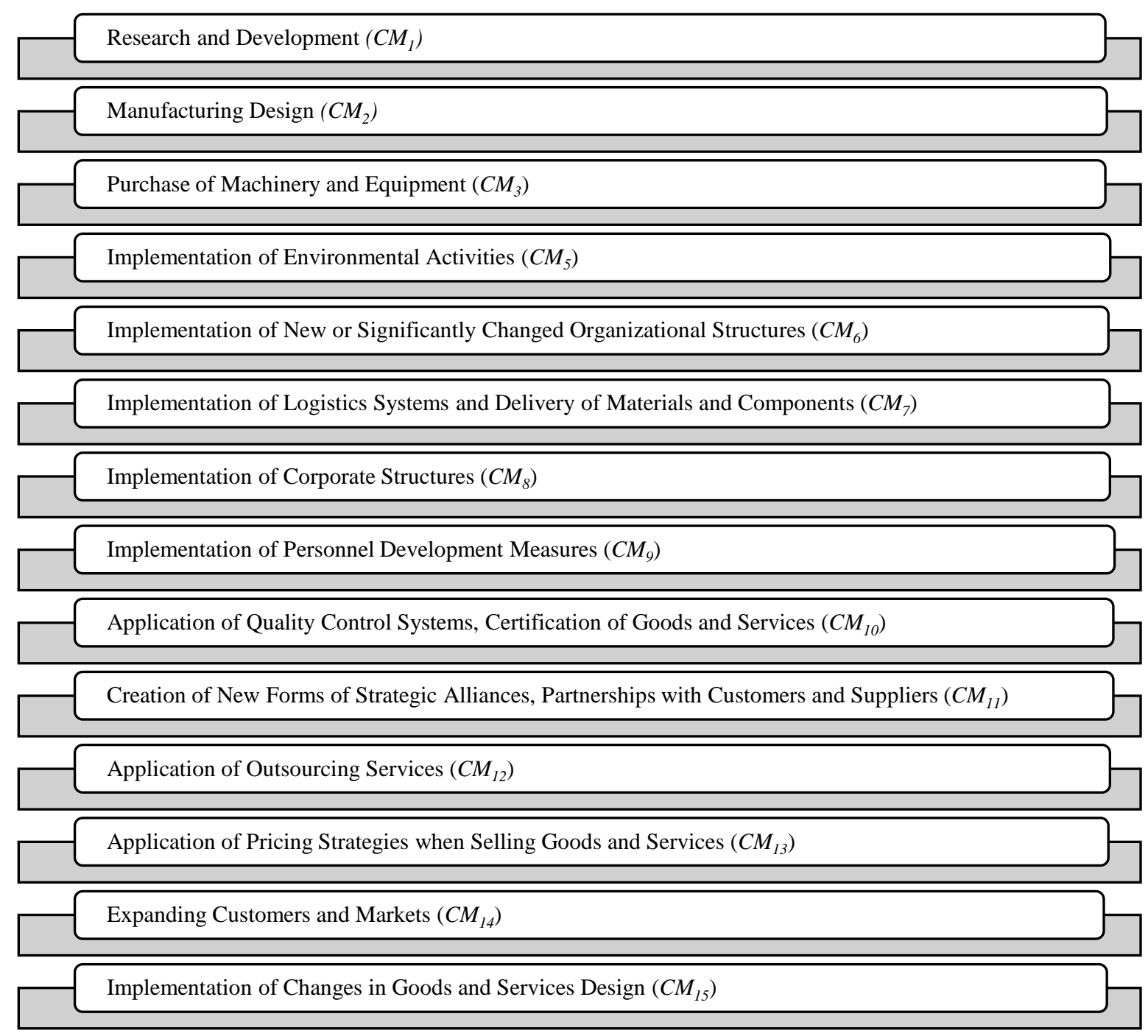

Figure 6. Control measures for the management of innovative activities of Russian industrial enterprises Source: Compiled by the authors

\section{DISCUSSION}

This study aims to specify the innovative development of industrial production in the digital economy of Russia. It is based on the methods of theoretical and empirical knowledge. It confirms the available information sources provided by the Interfax Corporate Information Disclosure Center.It also confirms the assumption that the innovative development of industrial production in Russia's digital economy is possible through a set of control actions under various scenarios.

The findings confirm the fact that industrial businesses that have integrated digital technologies into technological, organizational, marketing, and environmental processes can respond adequately to external challenges and threats and respond quickly to various risks. The main feature of the study is the reassessment of existing theoretical knowledge and generally accepted methods of innovative development management with a focus on algorithms and digitization methods to implement effective support for management decision-making in innovative development. The proposed directions provide a new level of quality management of innovative activities in the conditions of existing opportunities.

\section{CONCLUSION}

The analysis of 384 selected Russian industrial enterprises from 2015 to 2019 included both small and large enterprises. Many of these enterprises 
showed low levels of capital-labor ratio and labor productivity. The effort of most analyzed enterprises to achieve "financial independence" is explained by their strategy of stable sales and revenues. However, their innovative development requires more significant investment in research and development to create innovative products competitive in the domestic and foreign markets. The proposed set of control measures for the management of innovative activities of Russian industrial enterprises can serve as part of a general economic development management system. A new approach to managing the innovative activities of industrial enterprises will require a change in existing mechanisms and approaches to predicting the developments at regional and national levels.

\section{AUTHORS' CONTRIBUTIONS}

Oksana E. Ivanova: collection and analysis of materials, preparation of the concept of the paper. Mikhail S. Abrashkin, Yury V. Daneykin: general project management, analysis, and completion of the text of the paper. Martin Sikyr: analysis of the results and interpretation, literature processing, paper correction.

\section{REFERENCES}

[1] K.J. Breunig, T. Skjolsvik, "Understanding the strategy-innovation link in an era of disruptions", Technology Innovation Management Review, 2020, vol. 10(8), pp. 413. DOI: $10.22215 /$ timreview/1377

[2] M.Y. Veselovsky, T.V. Pogodina, R.V. Ilyukhina, T.A. Sigunova, N.F. Kuzovleva, "Financial and economic mechanisms of promoting innovative activity in the context of the digital economy formation", Entrepreneurship and Sustainability Issues, 2018, vol. 5(3), pp. 672-681. DOI: 10.9770/jesi.2018.5.3(19)

[3] M.K. Uandykova, "Integrated management of innovative development of the region on the basis of scenariated approach", MIR (Modernization. Innovation. Research), 2020, vol. 10(2), pp. 228-239. (In Russ.). DOI: $10.18184 / 2079-4665.2019 .10 .2 .228-239$

[4] A.E. Gorokhova, A.A. Efremov, V.D. Sekerin, "Development of an innovative product brand positioning on the example of pilotless buses in the Russian market", In Eds. by T. Loster, T. Pavelka, The 13th International Days of
Statistics and Economics, 2019, pp. 434-443. DOI: $10.18267 /$ pr.2019.los.186.43

[5] N.I. Komkov, A.A. Lazarev, V.S. Romantsov, "State and perspectives of development of domestic industrial companies", Studies on Russian Economic Development, 2020, vol. 31(2), pp. 212-222. DOI: $10.1134 / \mathrm{S} 1075700720020045$

[6] Digital economy of the Russian Federation. National projects, 2021. (In Russ.). Retrieved from: https://национальныепроекты.pф/projects

[7] M.Y. Veselovsky, J.V. Gnezdova, A.G. Glebova, V.A. Nikolskaya, A.Y. Lebedev, "Innovative Transformation of the Russian Industry in the Framework of Digital Technologies", Journal of ESPACIOS, 2018, vol. 39(41), p. 35.

[8] Interfax, Corporate Disclosure Centre, 2019. (In Russ.). Retrieved from: https://www.edisclosure.ru

[9] E. Milana, F. Ulrich, L.G.D. Faria, J. Li-Ying, "Exploring the impact of organizational, technological and relational contingencies on innovation speed in the light of open innovation", Industry and Innovation, 2020, vol. 27(4), pp. 804-836. DOI: $10.1080 / 13662716.2020 .1754170$

[10]P. Buyukbalc1, E. Ertemsir, Z. Boukari, "Embracing product innovativeness in technology firms: The impact of management model principles", Technology Innovation Management Review, 2020, vol. 10(12), pp. 31 45. DOI: $10.22215 /$ timreview/140

[11]N.I. Komkov, G.K. Kulanin, "Effect of innovative and technological activity of organizations on the volume of production of innovative goods and the growth of labor productivity", Studies on Russian Economic Development, 2020, vol. 31(4), pp. 376-384. DOI: $10.1134 / \mathrm{S} 1075700720040097$

[12] O.E. Ivanova, M.S. Abrashkin, V.T. Grishina, I.K. Zakharenko, "Modification of the financial security database in Russian industrial organizations", Revista Inclusiones, 2020, vol. 7, pp. 540-556.

[13]A. Barrichello, E.G. dos Santos, R.S. Morano, "Determinant and priority factors of innovation for the development of nations", Innovation \& Management Review, 2020, 
vol. 17(3), pp. 307-320. DOI: 10.1108/INMR04-2019-0040

[14] J. Li, R.P. Lee, J.B. Wan, "Indirect effects of direct subsidies: an examination of signaling effects", Industry and Innovation, 2020, vol. 27(9), pp. 1040-1061. DOI: $10.1080 / 13662716.2019 .1685375$
[15]R.A. Karayev, R.N. Mihailova, I.I. Safarly, N.Y. Sadikhova, X.F. Imamverdiyeva, "Cognitive tools for dynamic analysis of enterprise business strategies", Business Informatics, 2018, vol. 1, pp. 7-16. (In Russ.). DOI: 10.17323/1998-0663.2018.1.7.16 